\title{
Effect of the Increase of Energy Density on Knoop Hardness of Dental Composites Light-Cured by Conventional QTH, LED and Xenon Plasma Arc
}

\author{
Américo Bortolazzo CORRER \\ Mário Alexandre Coelho SINHORETI \\ Lourenço Correr SOBRINHO \\ Rubens Nisie TANGO \\ Luis Felipe Jochims SCHNEIDER \\ Simonides CONSANI
}

\author{
Dental Materials Area, Faculty of Dentistry of Piracicaba, \\ State University of Campinas (UNICAMP), Piracicaba, SP, Brazil
}

\begin{abstract}
The aim of this study was to evaluate the effect of the increase of energy density on Knoop hardness of Z250 and Esthet-X composite resins. Cylindrical cavities ( $3 \mathrm{~mm}$ in diameter X $3 \mathrm{~mm}$ in depth) were prepared on the buccal surface of 144 bovine incisors. The composite resins were bulk-inserted and polymerized using different light-curing units and times: conventional QTH (quartz-tungstenhalogen; $700 \mathrm{~mW} / \mathrm{cm}^{2} ; 20$ s, $30 \mathrm{~s}$ and 40 s); LED (light-emitting diode; $440 \mathrm{~mW} / \mathrm{cm}^{2} ; 20 \mathrm{~s}, 30 \mathrm{~s}$ and 40 s); PAC (xenon plasma arc; 1700 $\mathrm{mW} / \mathrm{cm}^{2} ; 3 \mathrm{~s}, 4.5 \mathrm{~s}$ and $6 \mathrm{~s}$ ). The specimens were stored at $37^{\circ} \mathrm{C}$ for $24 \mathrm{~h}$ prior to sectioning for Knoop hardness assessment. Three measurements were obtained for each depth: top surface, $1 \mathrm{~mm}$ and $2 \mathrm{~mm}$. Data were analyzed statistically by ANOVA and Tukey's test $(\mathrm{p}<0.05)$. Regardless of the light source or energy density, Knoop hardness of Z250 was statistically significant higher than that of Esthet-X $(p<0.05)$. Specimens cured with PAC had lower hardness than those cured with QTH and LED ( $<<0.05)$. Higher Knoop hardness was obtained when the energy density was increased for LED and PAC $(p<0.05)$. No statistically significant differences ( $>0.05$ ) were found for QTH. Knoop hardness values decreased with the increase of depth. The increase of energy density produced composites with higher Knoop hardness means using LED and PAC.
\end{abstract}

Key Words: composite resin, energy density, Knoop hardness, light curing, light sources.

\section{INTRODUCTION}

Composite resins are currently the most used esthetic restorative materials in Dentistry. Since their introduction, these materials have undergone continuous modifications. A major improvement was the introduction of ultraviolet light-activated composites, in the beginning of the 70's. Years later, light-cured composite resins activated by visible light were developed, which presented advantages such as lower risk of damage to the patient's health and higher polymerization depth in comparison to ultraviolet lightactivated resins (1).
Together with the advance of light-cured composites, light sources and light-curing techniques have also improved remarkably. Recently, LED (lightemitting diodes) and high intensity light-curing devices, such as xenon plasma arc (PAC) and lasers, have been introduced for curing of dental composites, as an alternative to conventional QTH (quartz-tungstenhalogen) units. LED and xenon plasma arc devices emit a narrow spectrum of light (at 450-490 nm), with the peak close to the peak of absorption of the camphoroquinone $(468 \mathrm{~nm})$. The specificity of the light emitted by LED is advantageous for polymerizing composites activated by the amine/camphoroquinone 
system. The use of filter to limit the width of the wavelength is not mandatory for LED, although they induce lower heating to tooth during light-curing (2). Current LED units promote considerable heating during the light activations of materials (3).

Xenon plasma arc is a high intensity light source that was introduced due to need for saving time during light-curing of composites (4). When PAC units are used, the manufacturers recommend $3 \mathrm{~s}$ of exposure time to polymerize composite resins that have camphoroquinone as photoinitiator system. However, it has been shown that the mechanical properties of composites light-cured by PAC with an exposure time as short as $3 \mathrm{~s}$ are compromised (4).

The narrow wavelength spectrum of LED and PAC is disadvantageous when the main photoinitiator system of composite resins is not camphoroquinone. The activation of another photoinitiator system that absorbs light out of LED and PAC emitting wavelengths cannot efficiently be done (5). Therefore, the low degree of conversion can originate composites with deficient mechanical properties (6) in addition to high citotoxity (7).

To induce composite polymerization and obtain high degree of conversion, it is necessary to provide the materials with appropriate energy density $(8,9)$. The energy density is the product of light intensity and exposure time. The energy density required to obtain optimal mechanical properties of the composites can vary depending on the shade, opacity, initiators and composition of the materials. Moreover, the increment volume and cavity configuration have an important role $(10,11)$. The light intensity should be compatible with the absorption wavelength spectrum of the photoinitiator systems. For camphoroquinone, which is the most used photoinitiator system in dental composites, the maximum absorption peak is within the blue spectrum of visible light, about $468 \mathrm{~nm}$ (12).

When similar energy densities are supplied to the composite resins, similar degrees of conversion and depth of polymerization will be obtained, regardless of the light-curing mode $(9,10)$. Increased degree of conversion can play important roles in the mechanical properties of composites, such as decrease of solubility, improvement of dimensional stability, lesser color alteration and greater biocompatibility (13). It is likely that composites with low mechanical properties will have short clinical life.
The purpose of this study was to evaluate the influence of the increase of energy density in the Knoop hardness of two dental composites (Z250 and Esthet$\mathrm{X}$ ), using three types of light sources for light-curing: conventional QTH, LED and PAC.

\section{MATERIAL AND METHODS}

For this study, 144 crowns of bovine incisors were embedded in PVC molds with polystyrene resin (Piraglass, Piracicaba, SP, Brazil) in such a way that the buccal surface remained exposed. After inclusion, the buccal surface was flattened in a polishing machine (APL-4; Arotec Ind. Com., Cotia, SP, Brazil) using \#180-grit sandpaper (Carborundum, Saint-Gobain Abrasivos Ltda, Cruz de Rebouças/Igaraçu, PE, Brazil). Cylindrical cavities (3 mm diameter; $3 \mathrm{~mm}$ deep) were prepared under water-cooling with \#3018 diamond burs (Metalúrgica FAVA Ind. e Com. Ltda, Franco da Rocha, SP, Brazil) mounted on an air-driven turbine (Kavo do Brasil S.A. Ind. e Com., Joinvile, SC, Brazil). The teeth were divided in two groups of 72 specimens each, according to the resin used for restoration: Z250 (3M/ESPE Dental Products, St Paul, MN, USA; A3 shade) or Esthet-X (Dentsply/Caulk, Milford, DE, USA; A3 shade).

The cavities were air-dried and Z250 and Esthet$\mathrm{X}$ composites were bulk-inserted. The filled cavities were covered with a polyester strip, which was manually pressed to remove composite excesses. The materials were light-cured with three light sources ( 24 specimens of each resin per light-curing unit): QTH (conventional halogen lamp) (XL2500; 3M/ESPE), LED (Ultrablue Is, D.M.C. Equipamentos Ltd. São Carlos, São Paulo, SP, Brazil) and PAC (Apollo 95E, DMD, Westlake Village, CA, USA).

Light intensities of $700 \mathrm{~mW} / \mathrm{cm}^{2}, 440 \mathrm{~mW} / \mathrm{cm}^{2}$ and $1700 \mathrm{~mW} / \mathrm{cm}^{2}$ were the maximum intensities of QTH, LED and PAC, respectively, checked with digital radiometer (Dental Hilux Curing Light; Dental Benlioglu Inc., Binnaz SK 1-6 Kavaklidere, Ankara, Turkey). According to the manufacturers' recommendations, the exposure time for Z250 and Esthet-X light-cured with QTH and LED units is $20 \mathrm{~s}$, and with PAC is $3 \mathrm{~s}$. Therefore, the groups polymerized with QTH for $20 \mathrm{~s}$, LED for $20 \mathrm{~s}$ and PAC for $3 \mathrm{~s}$ were considered as control groups. Eight specimens were used in each condition (exposure time). The energy densities used in each 
experimental condition for each light source (QTH, LED and PAC) are given in Table 1. Higher energy densities were obtained with longer exposure times. The light-curing protocols are described in Table 1.

Table 1. Light-curing protocols for the three types of light sources.

\begin{tabular}{lcccc}
\hline Light source & $\begin{array}{c}\text { Exposure } \\
\text { time }(\mathrm{s})\end{array}$ & $\begin{array}{c}\text { Light intensity } \\
\left(\mathrm{mW} / \mathrm{cm}^{2}\right)\end{array}$ & $\begin{array}{c}\text { Energy density } \\
\left(\mathrm{J} / \mathrm{cm}^{2}\right)\end{array}$ & $\begin{array}{c}\text { Energy density } \\
(\%)\end{array}$ \\
\hline \multirow{2}{*}{ QTH } & 20 & & 14.0 & $100 \%$ (control) \\
& 30 & 700 & 21.0 & $150 \%$ \\
& 40 & & 28.0 & $200 \%$ \\
LED & 20 & & & $100 \%$ (control) \\
& 30 & 440 & 13.2 & $150 \%$ \\
& 40 & & 17.6 & $200 \%$ \\
PAC & 3 & & 5.1 & $100 \%$ (control) \\
& 4.5 & 1700 & 7.5 & $150 \%$ \\
& 6 & & 10.2 & $200 \%$ \\
\hline
\end{tabular}

$\mathrm{QTH}$ = quartz-tungsten-halogen; LED = light-emitting diodes; $\mathrm{PAC}=$ xenon plasma arc.

Table 2. Knoop hardness means and standard deviation for Z250, at the three depths, for the different light sources.

\begin{tabular}{|c|c|c|c|}
\hline \multirow[t]{2}{*}{ Energy density } & \multicolumn{3}{|c|}{ Depth } \\
\hline & Top Surface & $1 \mathrm{~mm}$ & $2 \mathrm{~mm}$ \\
\hline \multicolumn{4}{|l|}{$100 \%$} \\
\hline QTH & $74.5 \pm 2.2 \mathrm{a}, \mathrm{A}$ & $72.8 \pm 2.2 \mathrm{a}, \mathrm{A}$ & $71.0 \pm 2.6 \mathrm{a}, \mathrm{A}$ \\
\hline LED & $72.9 \pm 3.4 \mathrm{a}, \mathrm{A}$ & $71.8 \pm 4.8 \mathrm{ab}, \mathrm{A}$ & $69.7 \pm 5.0 \mathrm{a}, \mathrm{A}$ \\
\hline PAC & $72.5 \pm 3.9$ a,A & $68.1 \pm 3.7$ b,B & $64.7 \pm 4.5 \mathrm{~b}, \mathrm{~B}$ \\
\hline \multicolumn{4}{|l|}{$150 \%$} \\
\hline QTH & $75.5 \pm 2.5 \mathrm{a}, \mathrm{A}$ & $74.1 \pm 3.3 \mathrm{ab}, \mathrm{A}$ & $73.3 \pm 2.3 \mathrm{a}, \mathrm{A}$ \\
\hline LED & $75.6 \pm 4.1 \mathrm{a}, \mathrm{A}$ & $75.3 \pm 3.0$ a,A & $74.4 \pm 2.4 \mathrm{a}, \mathrm{A}$ \\
\hline PAC & $73.3 \pm 2.8$ a,A & $70.7 \pm 3.8 \mathrm{~b}, \mathrm{AB}$ & $67.4 \pm 4.4 \mathrm{~b}, \mathrm{~B}$ \\
\hline \multicolumn{4}{|l|}{$200 \%$} \\
\hline QTH & $76.8 \pm 3.3 \mathrm{ab}, \mathrm{A}$ & $75.5 \pm 2.9$ a,A & $73.6 \pm 4.5 \mathrm{a}, \mathrm{A}$ \\
\hline LED & $78.6 \pm 2.8$ a,A & $75.5 \pm 3.7$ a,AB & $72.9 \pm 2.8 \mathrm{a}, \mathrm{B}$ \\
\hline PAC & $74.1 \pm 2.9 \mathrm{~b}, \mathrm{~A}$ & $73.3 \pm 2.9$ a,A & $71.0 \pm 4.1 \mathrm{a}, \mathrm{A}$ \\
\hline
\end{tabular}

QTH = quartz-tungsten-halogen; LED = light-emitting diodes; PAC = xenon plasma arc. Means followed by different lowercase letters in the columns for each energy densitiy and uppercase letters in the rows for each depth indicate statistically significant difference at $5 \%$. $37^{\circ} \mathrm{C}$ during $24 \mathrm{~h} \pm 1$ in a dry, light-proof con Twenty-four hours after photoactivation, the specimens were sectioned in mesiodistal direction with a diamondwafering blade (Extec Corp., Enfield, CT, USA) mounted in a metalographic cutter (Isomet 1000, Buhler, Lake Bluff, IL, USA) under water-cooling. After sectioning, the specimens were ground and polished with 320-, 400-, 600- and 1200-grit sandpapers (Carborundum; Saint-Gobain Abrasivos Ltda) on an automated polisher under water cooling.

The specimens were dried and submitted to Knoop hardness measurements in a microhardness tester (HMV-2000, Shimadzu, Tokyo, Japan) with load of $50 \mathrm{~g}$ and time of 15 s. Knoop hardness readings were accomplished on top surface, 1 and 2 $\mathrm{mm}$ deep. For each depth, three readings were taken and an average was calculated.

Data were analyzed statistically by ANOVA and the means were compared by Tukey's test at the 5\% significance level.

\section{RESULTS}

Knoop hardness of Z250 (72.9 KHN) was statistically significant higher $(\mathrm{p}<0.05)$ than that of Esthet-X (56.0 KHN).

In general, the specimens cured with PAC presented lower Knoop hardness means than those photoactivated with QTH and LED. Z250 specimens light-cured with PAC presented lower Knoop hardness means starting from $1 \mathrm{~mm}$ depth, for energy densities of 100 and 150\%. With 200\%, significant differences among the methods were observed only on the top surface (Table 2).

Esthet-X specimens light-cured with PAC showed lower Knoop 
Table 3. Knoop hardness means and standard deviation for Esthet-X, at the three depths, for the different light sources.

\begin{tabular}{|c|c|c|c|}
\hline \multirow[t]{2}{*}{ Energy density } & \multicolumn{3}{|c|}{ Depth } \\
\hline & Top Surface & $1 \mathrm{~mm}$ & $2 \mathrm{~mm}$ \\
\hline \multicolumn{4}{|l|}{$100 \%$} \\
\hline QTH & $57.8 \pm 2.5 a, A$ & $55.9 \pm 1.7$ a, $\mathrm{AB}$ & $53.4 \pm 2.5 \mathrm{a}, \mathrm{B}$ \\
\hline LED & $58.6 \pm 1.9$ a,A & $56.0 \pm 2.6 \mathrm{a}, \mathrm{AB}$ & $53.0 \pm 1.6 \mathrm{a}, \mathrm{B}$ \\
\hline PAC & $56.8 \pm 4.1 \mathrm{a}, \mathrm{A}$ & $54.1 \pm 4.0 \mathrm{a}, \mathrm{A}$ & $45.8 \pm 5.7 \mathrm{~b}, \mathrm{~B}$ \\
\hline \multicolumn{4}{|l|}{$150 \%$} \\
\hline QTH & $56.3 \pm 3.0$ a,A & $57.2 \pm 2.2 \mathrm{a}, \mathrm{AB}$ & $55.7 \pm 2.1 \mathrm{a}, \mathrm{B}$ \\
\hline LED & $58.4 \pm 2.6 \mathrm{a}, \mathrm{A}$ & $56.4 \pm 2.3 \mathrm{a}, \mathrm{AB}$ & $53.8 \pm 2.5 \mathrm{a}, \mathrm{B}$ \\
\hline PAC & $58.4 \pm 1.9$ a,A & $55.7 \pm 3.3 \mathrm{a}, \mathrm{A}$ & $49.4 \pm 4.4 \mathrm{~b}, \mathrm{~B}$ \\
\hline \multicolumn{4}{|l|}{$200 \%$} \\
\hline QTH & $59.9 \pm 4.3 \mathrm{a}, \mathrm{A}$ & $57.8 \pm 2.6$ a,A & $56.3 \pm 2.5 \mathrm{a}, \mathrm{A}$ \\
\hline LED & $60.6 \pm 3.2 \mathrm{a}, \mathrm{A}$ & $58.7 \pm 2.7 \mathrm{a}, \mathrm{AB}$ & $55.2 \pm 3.2 \mathrm{ab}, \mathrm{B}$ \\
\hline PAC & $60.2 \pm 3.1 \mathrm{a}, \mathrm{A}$ & $56.5 \pm 2.2$ a,A & $51.5 \pm 3.7$ b,B \\
\hline
\end{tabular}

QTH = quartz-tungsten-halogen; LED = light-emitting diodes; PAC = xenon plasma arc. Means followed by different lowercase letters in the columns for each energy densitiy and uppercase letters in the rows for each depth indicate statistically significant difference at $5 \%$.

Table 4. Knoop hardness means and standard deviation for Z250, at the three depths, for the different energy densities.

\begin{tabular}{|c|c|c|c|}
\hline \multirow[t]{2}{*}{ Light source } & \multicolumn{3}{|c|}{ Depth } \\
\hline & Top Surface & $1 \mathrm{~mm}$ & $2 \mathrm{~mm}$ \\
\hline \multicolumn{4}{|l|}{ QTH } \\
\hline $100 \%$ & $74.5 \pm 2.2 \mathrm{a}$ & $72.8 \pm 2.2 \mathrm{a}$ & $71.0 \pm 2.6 \mathrm{a}$ \\
\hline $150 \%$ & $75.5 \pm 2.5 \mathrm{a}$ & $74.1 \pm 3.3 \mathrm{a}$ & $73.3 \pm 2.3 \mathrm{a}$ \\
\hline $200 \%$ & $76.8 \pm 3.3 \mathrm{a}$ & $75.5 \pm 2.9 \mathrm{a}$ & $73.6 \pm 4.5 \mathrm{a}$ \\
\hline \multicolumn{4}{|l|}{ LED } \\
\hline $100 \%$ & $72.9 \pm 3.4 b$ & $71.8 \pm 4.8 \mathrm{a}$ & $69.7 \pm 5.0 \mathrm{~b}$ \\
\hline $150 \%$ & $75.6 \pm 4.1 \mathrm{ab}$ & $75.3 \pm 3.0 \mathrm{a}$ & $74.4 \pm 2.4 \mathrm{a}$ \\
\hline $200 \%$ & $78.6 \pm 2.8 \mathrm{a}$ & $75.5 \pm 3.7 \mathrm{a}$ & $72.9 \pm 2.8 \mathrm{ab}$ \\
\hline \multicolumn{4}{|l|}{ PAC } \\
\hline $100 \%$ & $72.5 \pm 3.9 \mathrm{a}$ & $68.1 \pm 3.7 \mathrm{~b}$ & $64.7 \pm 4.5 b$ \\
\hline $150 \%$ & $73.3 \pm 2.8 \mathrm{a}$ & $70.7 \pm 3.8 \mathrm{ab}$ & $67.4 \pm 4.4 \mathrm{ab}$ \\
\hline $200 \%$ & $74.1 \pm 2.9 \mathrm{a}$ & $73.3 \pm 2.9 \mathrm{a}$ & $71.0 \pm 4.1 \mathrm{a}$ \\
\hline
\end{tabular}

QTH = quartz-tungsten-halogen; LED = light-emitting diodes; PAC = xenon plasma arc. Means followed by different letters in columns for each light source indicate statistically significant difference at $5 \%$. hardness means at $2 \mathrm{~mm}$ depth, for the three energy densities (Table 3). There was no statistically significant difference for Knoop hardness between QTH and LED ( $p>0.05)$ (Table 2 and Table 3).

Table 2 shows that, for Z250, Knoop hardness on top surface was statistically higher than at 1 and $2 \mathrm{~mm}$ depth when PAC was used with $100 \%$ energy density $(\mathrm{p}<0.05)$. For $150 \%$ energy density, the hardness on the top surface was statistically higher than at $2 \mathrm{~mm}(\mathrm{p}<0.05)$. For $200 \%$, there was no significant difference ( $>0.05$ ) among the depths. When LED was used, the hardness on the top surface was higher than that at 2 mm only for $200 \%$ energy density. For QTH, there was no statistically significant difference $(p>0.05)$ among the depths for all energy densities.

Table 3 shows that, for Esthet$\mathrm{X}$, Knoop hardness on the top surface was statistically higher than that at 2 mm depth for $100 \%$ and $150 \%$ energy densities, when conventional QTH unit was used $(\mathrm{p}<0.05)$. For $200 \%$ energy density, there was no statistical difference among the depths ( $>>0.05)$. For LED, the hardness on the top surface was statistically higher than that at $2 \mathrm{~mm}$ depth for all energy densities $(p<0.05)$. For PAC, the hardness on the top surface and 1 mm were statistically higher than that at $2 \mathrm{~mm}$ depth for all energy densities $(\mathrm{p}<0.05)$.

Regarding energy density for Z250 (Table 4), Knoop hardness using $100 \%$ energy density was lower than other energy densities for LED and PAC $(p<0.05)$, except for LED at 1 $\mathrm{mm}$ and PAC on the top surface. For QTH, there was no significant difference for Knoop hardness among the energy densities ( $p>0.05$ ). 
For Esthet-X (Table 5), Knoop hardness for $100 \%$ energy density was statistically lower than that for $200 \%$ energy density when PAC was used, only at $2 \mathrm{~mm}$ depth $(\mathrm{p}<0.05)$. For QTH and LED there was no difference among the energy densities, for all depths $(\mathrm{p}<0.05)$.

\section{DISCUSSION}

The hardness of composites is influenced by several factors, such as organic matrix composition (14), type and amount of filler particles (15) and degree of conversion (16). In this study, the Knoop hardness of Z250 was higher than that of Esthet-X. The organic matrix of Z250 is composed mainly by BisGMA, UDMA and BisEMA, and the inorganic particles are zircon/silica (60\% in volume). In contrast, the organic matrix of Esthet- $X$ is composed mainly by urethane modified BisGMA, BisEMA and TEGDMA, and a combination of inorganic particles of aluminum fluorine borosilicate glass and silanized barium, colloidal and nanometric silica (60\% in volume). The higher Knoop hardness means obtained for Z250 may be explained by differences in filler type and organic matrix composition between

Table 5. Knoop hardness means and standard deviation for Esthet-X, at the three depths, for the different energy densities.

\begin{tabular}{lccc}
\hline Light source & \multicolumn{3}{c}{ Depth } \\
\cline { 2 - 4 } & Top Surface & $1 \mathrm{~mm}$ & \\
& & $\mathrm{~mm}$ \\
QTH & & & \\
$100 \%$ & $57.8 \pm 2.5 \mathrm{a}$ & $55.9 \pm 1.7 \mathrm{a}$ & $53.4 \pm 2.5 \mathrm{a}$ \\
$150 \%$ & $60.3 \pm 3.0 \mathrm{a}$ & $57.2 \pm 2.2 \mathrm{a}$ & $55.7 \pm 2.1 \mathrm{a}$ \\
$200 \%$ & $59.9 \pm 4.3 \mathrm{a}$ & $57.8 \pm 2.6 \mathrm{a}$ & $56.3 \pm 2.5 \mathrm{a}$ \\
& & & \\
LED & & & $56.0 \pm 1.6 \mathrm{a}$ \\
$100 \%$ & $58.6 \pm 1.9 \mathrm{a}$ & $56.0 \pm 2.6 \mathrm{a}$ & $53.8 \pm 2.5 \mathrm{a}$ \\
$150 \%$ & $58.4 \pm 2.6 \mathrm{a}$ & $56.4 \pm 2.3 \mathrm{a}$ & \\
$200 \%$ & $60.6 \pm 3.2 \mathrm{a}$ & $58.7 \pm 2.7 \mathrm{a}$ & \\
PAC & & & $45.8 \pm 5.7 \mathrm{~b}$ \\
$100 \%$ & & & $51.5 \pm 3.7 \mathrm{a}$ \\
$150 \%$ & $56.8 \pm 4.1 \mathrm{a}$ & $54.1 \pm 4.0 \mathrm{a}$ & \\
$200 \%$ & $58.4 \pm 1.9 \mathrm{a}$ & $55.7 \pm 3.3 \mathrm{a}$ & \\
\hline
\end{tabular}

QTH = quartz-tungsten-halogen; LED = light-emitting diodes; PAC = xenon plasma arc. Means followed by different letters in columns for each light source indicate statistically significant difference at $5 \%$. both materials. Craig (17) suggested that composites with harder filler particles exhibit higher surface hardness. However, the bond of the filler particles to the polymeric matrix also affects their hardness.

Many studies have shown that the degree of conversion depends more on the amount of energy supplied to the composite than on the light-curing method (9). Hardness evaluation is an indirect method to verify the degree of conversion of resin composites (16). Hardness values show a positive correlation with degree of conversion.

The findings of this study are consistent with those of a previous investigation (18), which concluded that higher hardness can be obtained by increasing exposure time and energy density. Z250 specimens light-cured with LED and PAC had higher Knoop hardness when increased energy densities were used. For Esthet-X specimens photoactivated with PAC, there was an increase in Knoop hardness when longer exposure times were used. The increase in energy density produced higher degree of conversion and, consequently, higher Knoop hardness means.

The comparison among the light sources showed that PAC yielded the worst Knoop hardness means.

Degree of conversion depends on the amount of energy supplied to the composite. Low energy density produces composites with low degree of conversion and deficient mechanical properties, such as Knoop hardness (6). Due to short exposure time, even with high light intensity, the low energy density supplied using the PAC unit produced specimens with lower Knoop hardness.

There was no statistically significant difference in Knoop hardness means between LED and QTH up to $2 \mathrm{~mm}$ depth. Although the halogen lamp has higher energy density than the LED source, many of the emitted photons are out of the spectrum of absorption of the camphoroquinone (5). Therefore, the triplex state of the camphoroquinone is not activated. For LED, the narrow wavelength 
spectrum is within the spectrum of absorption of the camphoroquinone and the specific energy density for camphoroquinone is higher, compensating the lower light intensity emitted by these devices. The recent progresses in LED technology made possible to obtain devices with higher light intensity, which allows lightcuring with shorter exposure times (20 s) and enough energy densities to produce composites with improved mechanical properties (19).

Regarding to the polymerization depth, the hardness values decreased towards deeper layers. The polymerization depth of light-cured composites depends on the composition, shade and translucence of the restorative material, intensity of the light source and distance of the tip of the light-curing device to the material surface (20). All those factors influence the amount of light that reach the deepest layers of the material. If the amount of light is not sufficient, the degree of conversion in these areas is low and the mechanical properties of the material, including Knoop hardness, are affected negatively.

It could be observed in this study that the increase of energy density influenced Knoop hardness values in deeper areas of the restoration, mainly for Z250 specimens light-cured with LED or PAC. Therefore, the knowledge and the understanding of the mechanisms that can impair light curing of composites associated with the use of techniques that can minimize the occurrence of problems could help the clinicians to obtain the maximum benefits of these materials in daily clinical practice.

Based on the results of this study, it may be concluded that Knoop hardness means of Z250 was higher than those of Esthet-X. The increase of energy density produced higher Knoop hardness when Z250 composite was photoactivated with LED and PAC. For Esthet- $X$, the increase in energy density produced higher Knoop hardness solely when PAC was used. Both composites photoactivated with PAC presented the lowest Knoop hardness means in comparison to light-activation with the other sources. No significant differences on Knoop hardness were observed when the composites were light-cured with QTH or LED.

\section{RESUMO}

Este estudo teve como objetivo avaliar o efeito do aumento da densidade de energia na dureza Knoop das resinas compostas Z250 e Esthet-X. Cavidades cilíndricas (3 mm de diâmetro X 3 mm de profundidade) foram preparadas na superfície vestibular de 144 incisivos bovinos. As resinas compostas foram inseridas em incremento único e fotopolimerizadas com diferentes unidades e tempos de fotopolimerização: luz halógena convencional (700 $\mathrm{mW} / \mathrm{cm}^{2} ; 20 \mathrm{~s}, 30 \mathrm{~s}$ and $40 \mathrm{~s}$ ); LED (diodo emissor de luz; 440 $\mathrm{mW} / \mathrm{cm}^{2} ; 20 \mathrm{~s}, 30 \mathrm{~s}$ and $40 \mathrm{~s}$ ); PAC (arco de plasma de xenônio; $1700 \mathrm{~mW} / \mathrm{cm}^{2} ; 3 \mathrm{~s}, 4,5 \mathrm{~s}$ and $6 \mathrm{~s}$ ). Os espécimens foram armazenados a $37^{\circ} \mathrm{C}$ durante $24 \mathrm{~h}$, previamente à realização das leituras de dureza Knoop. Foram realizadas três leituras por profundidade: superfície, $1 \mathrm{~mm}$ e $2 \mathrm{~mm}$. Os dados foram submetidos à ANOVA e ao teste de Tukey $(\mathrm{p}<0,05)$. Independente da unidade de fotopolimerização ou da densidade de energia, a dureza do compósito Z250 foi estatisticamente superior do que o compósito Esthet- $\mathrm{X}(\mathrm{p}<0.05)$. A dureza dos compósitos fotoativados por PAC foi estatisticamente inferior em relação aos compósitos fotoativados por luz halógena ou LED $(\mathrm{p}<0.05)$ que, por sua vez, não diferiram entre si, independentemente da profundidade. $\mathrm{O}$ aumento do tempo de exposição produziu compósitos com maiores valores de dureza Knoop quando se utilizou LED ou PAC $(\mathrm{p}<0.05)$. Para luz halógena o aumento do tempo de exposição não influenciou os valores de dureza $(\mathrm{p}>0.05)$. Os valores de dureza Knoop diminuíram com o aumento da profundidade. O aumento da densidade de energia produziu compósitos com maior dureza Knoop quando o LED e o PAC foram utilizados como fontes de polimerização.

\section{REFERENCES}

1. Ruyter IE, Oysaed H. Conversion in different depths of ultraviolet and visible light activated composite materials. Acta Odontol Scand 1982;40:179-192.

2. Kurachi C, Tuboy AM, Magalhães DV, Bagnato VS. Hardness evaluation of a dental composite polymerized with experimental LED-based devices. Dent Mater 2001;17:309315.

3. Uhl A, Mills RW, Jandt KD. Polymerization and light-induced heat of dental composites cured with LED and halogen technology. Biomaterials 2003;24:1809-1820.

4. Peutzfeldt A, Sahafi A, Asmussen E. Characterization of resin composites polymerized with plasma arc curing units. Dent Mater 2000;16:330-336.

5. Hofmann N, Hugo B, Klaiber B. Effect of irradiation type (LED or QTH) on photo-activated composite shrinkage strain kinetics, temperature rise, and hardness. Eur J Oral Sci 2002;110:471-479.

6. Emami N, Söderholm KJM, Berglund LA. Effect of light power density variations on bulk curing properties of dental composites. J Dent 2003;31:189-196.

7. Caughman WF, Caughman GB, Shiflett RA, Rueggeberg FA, Schuster GS. Correlation of cytotoxicity, filler loading and curing time of dental composites. Biomaterials 1991;12:737740.

8. Miyazaki M, Oshida Y, Moore BK, Onose H. Effect of light exposure on fracture toughness and flexural strength of lightcured composites. Dent Mater 1996;12:328-332.

9. Halvorson RH, Erickson RL, Davidson CL. An energy conversion relationship predictive of conversion profiles and depth of cure for resin-base composites. Oper Dent 2003;28:307-314.

10. Nomoto R, Uchida K, Hirasawa T. Effect of light intensity on 
polymerization of light-cured composite resins. Dent Mater J 1994;13:198-205.

11. Rueggeberg FA, Caughman WF, Curtis Jr JW. Effect of light intensity and exposure duration on cure of resin composite. Oper Dent 1994;19:26-32.

12. Nomoto R. Effect of wavelength on polymerization of lightcured resins. Dent Mater J 1997;16:60-73.

13. Ferracane, JL. Elution of leachable components from composites. J Oral Rehabil 1994;21:441-452.

14. Asmussen E. Restorative resins: hardness and strength vs. quantity of remaining double bonds. Scand J Dent Res 1982;90:484-489.

15. Chung KH, Greener EH. Correlation between degree of conversion, filler concentration and mechanical properties of posterior composite resins. J Oral Rehabil 1990;17:487494.
16. Ferracane JL. Correlation between hardness and degree of conversion during the setting reaction of unfilled dental restorative resins. Dent Mater 1985;1:11-14.

17. Craig RG. Restorative dental materials. 10th ed. St Louis: Mosby; 1997.

18. Correr Sobrinho L, De Goes MF, Consani S, Sinhoreti MAC, Knowles JC. Correlation between light intensity and exposure time on the hardness of composite resin. J Mat Sci Mater Med 2000;11:361-364.

19. Soh MS, Yap AUJ. Influence of curing modes on crosslink density in polymer structures. J Dent 2004;32:321-326.

20. Leloup G, Holvoet PE, Bebelman S, Devaux J. Raman scattering determination of the depth of cure of lightactivated composites: influences of different clinically relevant parameters. J Oral Rehabil 2002;29:510-515.

Accepted March 5, 2005 